\title{
腎孟腫瘍に併発する尿管・膀胱腫瘍の検討
}

\begin{tabular}{|c|c|c|c|c|}
\hline & 仲 & 田 浄 & 治 & 郎 \\
\hline & 増 & 田富 & $士$ & 男 \\
\hline & 大 & 石 & 幸 & 彦 \\
\hline 東京慈恵会医科大学泌尿器科学教室 & 小 & 路 & & 良 \\
\hline & 陳 & 瑞 & & 些 \\
\hline & 大 & 西 & 哲 & 即 \\
\hline & 町 & 田 & 豊 & \\
\hline 国立王子病院泌尿器科 & 佐 & 々 木 & 忠 & $\mathrm{H}$ \\
\hline 国立西埼玉中央病院泌尿器科 & 谷 & 野 & & \\
\hline & 古 & 里 & 征 & 国 \\
\hline & 鈴 & 木 & 良 & \\
\hline 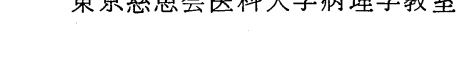 & 藍 & 沢 & 茂 & \\
\hline & 石 & 川 & 栄 & \\
\hline
\end{tabular}

\section{THE STUDY OF THE URETER AND/OR BLADDER TUMORS ASSOCIATED WITH UROTHELIAL LESION OF THE RENAL PELVIS}

\author{
Gyojiro Nakada, Fujio Masuda, Yukihiko Ouishi, Ryo Shoji, Zuisho Chen, \\ Tetsuro Onishi and Toyohei Machida \\ Department of Urology, The Jikei University School of Medicine, Tokyo, Japan \\ (Director: Prof. T. Machida) \\ Tadamasa Sasaki \\ Department of Urology, Ouji National Hospital \\ Makoto Tanino \\ Department of Urology, Nishisaitama Chuo National Hospital \\ Masakuni Furusato, Ryoji Suzuki, Shigeo Aizawa and Eisei Ishikawa \\ Department of Pathology, The Jikei University School of Medicine, Tokyo, Japan
}

Transitional cell carcinoma of the renal pelvis has been encountered in 54 cases at the Jikei University Hospital and related facilities.

The purpose of this review was to determine the association of ureter and bladder lesion with the renal pelvic tumor.

There were 14 women and 40 men (a ratio of 1.0 to 2.9). The range of age was from 22 to 78 years with an average of 59 .

Twenty-six of the 54 patients (48\%) with urotherial tumors of the renal pelvis had a synchronous or asynchronous tumor in the ureter and/or bladder. Seven of 20 patients were found to have bladder tumors concurrent with their renal pelvic neoplasms. Subsequent bladder tumor occurred in 13 of 20 patients. It developed 3 to 26 months (average 9.8 months) after the treatment of the pelvic tumor. Two cases had a previous history of bladder tumor. 
High recurrence rate of the bladder tumor was observed with the association of multifocal tumors of upper urinary tract lesions at the time of operation. From the point of surgical treatment the recurrent bladder tumor was much more satisfactorily prevented by complete nephro-ureterectomy including a cuff of bladder.

Histopathologically the grading of the bladder tumors was usually simillar to that of original pelvic lesion. And the majority of bladder lesions were superficial.

要旨 : 慈恵大学病院扢よび関連病院で過去28年間に経験した腎盂移行上皮癌54例について主として併発する尿 管腫瘍, 膀朕腫瘍に関して検討した。症例は男子 40 例, 女子14例（男女比 $2.9: 1$ ）で年齢は $22 〜 78$ 歳, 平均 59歳であつた。

腎㙉腫瘍54例中，尿管または膀脂腫瘍を併発したものは26例，48\%であつた. 膀羘腫瘍の発生時期をみる と，腎孟腫瘍診断と同時に認められたものは20例中 7 例であり，13例は術後に発生し，その期間は $3 \sim 26 カ$ 月，平均9.8カ月であつた．また 2 例は膀胱腫瘍の治療後に腎盂腫瘍が発見された． 術後膀羘腫瘍の発生した 症例についてみると, 術前に上部尿路の広範囲に腫瘍が発生している場合に頻度は高く, 術式では膀胱壁内尿 管を含め腎尿管全摘除術を施行した場合に，発生頻度は少ない傾向がみられた。な拉病理組織学的検査では膀 胱腫瘍の Grade は腎孟腫瘱の Grade と類似している場合が多くままた多くは表在性腫瘍であつた.

\section{緒言}

腎盂移行上皮癌の特徴の 1 つとして, 他の尿路上皮に も同じ移行上皮性の腫瘍が発生することがある。しかし 腎盂移行上皮癌は腎実質腫瘍に比べて比較的稀なため， 併発腫場（同時抢よび異時発生）については十分な検討 がなされていない。

われわれは慈恵大学病院扣よびその関連病院で54例の 腎盂移行上皮癌を経験しているがこれら腎㙉腫瘍に併発 する尿路上皮腫瘍を，性別，年齡，手術時腫瘍の範囲， 手術術式, grade 及び stage について比較検討し報告す る.

\section{臨床成繶}

対象は1953年から1980年までに診察した54例で，平均 年龄は59歳であり，性別では男子 40 例 $(74 \%)$ ，女子 14 例 $(26 \%)$ と男子が多い，患側は右側 25 例，左側29例で あつた。全症例，手術を施行し，その術式は腎尿管全摘 除術兼膀脂壁切除術は40例，腎尿管摘除術 4 例，腎摘除 術10例であつた。

対象54例中, 組織像が再検できた 48 例について病理学 的検討を行つた. 病理組織学的 grade は WHO 分類に より grade Iからでに分けまた stage は Jewett の分類にしたがつて stage I からIVに分類した. 上述 の組織学的分類によると grade I は11例で，そのらち stage I が 9 例であり, grade II の30例では stage II 以 上が21例であつた（表 1 ）。

1. 併発の頻度

腎盂移行上皮癌54例中，尿管または膀胱にも移行上皮 腫崵の発生したものは26例（48\%）であつた. 26例中11
表 1 腎孟腫瘍の Grade と Stage

\begin{tabular}{l|c|c|c|c|c}
\hline & Stage I & Stage II & Stage II & Stage IV & total \\
\hline Grade I & 9 & 2 & 0 & 0 & 11 \\
\hline Grade II & 9 & 9 & 10 & 2 & 30 \\
\hline Grade III & 1 & 1 & 1 & 0 & 3 \\
\hline Undifferentiated & 0 & 0 & 2 & 0 & 2 \\
\hline Non papillary & 2 & 0 & 0 & 0 & 2 \\
\hline \multicolumn{1}{c|}{ total } & 21 & 12 & 13 & 2 & 48 \\
\hline & & & \multicolumn{3}{c}{ (慈大, 泌, 1980) }
\end{tabular}

例は尿管および膀胱に，6 例は尿管のみに，9例は膀脱 のみに生じていた。

\section{2. 年齢}

全54例の腎盂腫瘍のうち腎盂のみの腫瘍28例の平均年 龄は57.6歳であるのに対し，尿管や膀胱に腫瘍が併発し た26例の平均年齢は60.5歳であり，特に同時発生例11例 では平均年齢65歳と高齢であつた（表 2 ）.

3. 性別

全54例の腎盂腫瘍のらち，腎盂のみの腫瘍28例では， 男子 20 例 $(65 \%)$ ，女子 8 例 (35\%) 飞対し，尿管・膀 脱飞併発した 26 例では，男子20例 $(77 \%)$ ，女子6例 （23\%）であり，男子は女子に比べて腎典腫瘍が多いの みならず，康路の他の部位にも多発しやすい傾向がみら れた（表 3 ).

4. 手術時の腫瘍の範囲

手術時の腫瘍の範囲と，その後に続発した尿路上皮腫 瘍の関係をみると，手術時に腫瘍が腎孟のみにみられた 
表 2 腎孟腫瘍の年龄

\begin{tabular}{|c|c|c|c|c|c|}
\hline \multirow{2}{*}{ 年榆 } & \multirow{2}{*}{$\begin{array}{c}\text { 腎舌のみ } \\
\text { の腫 瘍 } \\
\text { 例数 } \\
(\%)\end{array}$} & \multicolumn{4}{|c|}{ 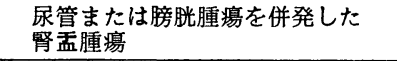 } \\
\hline & & 同時 & 異時 & $\begin{array}{l}\text { 同時加 } \\
\text { つ異時 }\end{array}$ & $\begin{array}{l}\text { 総例数 } \\
(\%)\end{array}$ \\
\hline $20 \sim 29$ & $1(3.6)$ & 0 & 0 & 0 & $0(\quad 0)$ \\
\hline $30 \sim 39$ & $1(3.6)$ & 0 & 1 & 0 & $1(3.8)$ \\
\hline $40 \sim 49$ & $4(14.3)$ & 0 & 2 & 2 & $4(15.4)$ \\
\hline $50 \sim 59$ & $9(32.1)$ & 3 & 2 & 1 & $6(23.1)$ \\
\hline $60 \sim 69$ & $10(35.7)$ & 4 & 3 & 2 & $9(34.6)$ \\
\hline $70 \sim 79$ & $3(10.7)$ & 4 & 1 & 1 & $6(23.1)$ \\
\hline 平均年齢 & 57.6 & 65 & 57 & 60 & 60.5 \\
\hline 最年少 & 22 & 50 & 39 & 46 & 39 \\
\hline 最 年 長 & 77 & 78 & 74 & 78 & 78 \\
\hline
\end{tabular}

(慈大, 泌, 1980)

表 3 腎血腫湐の性別

\begin{tabular}{|c|c|c|c|c|c|}
\hline \multirow{2}{*}{ 性 別 } & \multirow{2}{*}{ 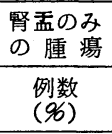 } & \multicolumn{4}{|c|}{$\begin{array}{l}\text { 层管または膀腅腫瘍を併発した } \\
\text { 腎監腫瘍 }\end{array}$} \\
\hline & & 同時 & 異時 & $\begin{array}{l}\text { 同時加 } \\
\text { つ異常 }\end{array}$ & $\begin{array}{l}\text { 総例数 } \\
(\%)\end{array}$ \\
\hline 男 性 & $20(65)$ & 9 & 7 & 4 & $20(77)$ \\
\hline 女性 & $8(35)$ & 2 & 2 & 2 & $6(23)$ \\
\hline 計 & $28(100)$ & 11 & 9 & 6 & $26(100)$ \\
\hline
\end{tabular}

(慈大, 泌, 1980)

35例では膀胱腫瘍が 7 例 (20\%) 飞，腎孟とともに尿管 にも腫瘍が認められた10例では 4 例 $(40 \%)$ 飞，尿管及 び膀胱にも腫瘍が存在していた 5 例では 2 例（40\%）が 術後に膀胱腫瘍が発生している（表 4 ）.

5. 手術術式

手術時, 腎盂のみに腫瘍がみられた35例について術式

表 4 手術時の腫瘍の範囲と術後膀腅腫瘍の発生

\begin{tabular}{|c|c|c|}
\hline 手術時腫瘍の範囲 & 例数 & $\begin{array}{c}\text { 続発性膀胱腫瘍 } \\
\text { 例数 }(\%) \text { ) }\end{array}$ \\
\hline 腎孟腫瘍 & 35 & $7(20)$ \\
\hline 腎孟尿管腫瘍 & 10 & $4(40)$ \\
\hline 腎孟尿管膀胱腫湯 & 5 & $2(40)$ \\
\hline 腎孟膀朕腫瘍 & 2 & $0(0)$ \\
\hline $\begin{array}{l}\text { 膀腅腫瘍術後に } \\
\text { 発生した腎覀腫瘍） }\end{array}$ & (2) & $0(0)$ \\
\hline 計 & $54(2)$ & $13(25)$ \\
\hline
\end{tabular}

(慈大, 泌, 1980)
と術後膀胱腫瘍の発生についてみると，尿管口周囲の膀 脂壁を含めて腎尿管全摘除術を施行した24例では，術後 膀胱腫瘍が 発生したのは 2 例 $(8.3 \%)$ で，壁内尿管を のこした 3 例では1例 $(33 \%)$ であつた。

一方，腎摘除術の及を行なつた 8 例では 4 例（50\%） 飞術後膀脱腫痬が発生して扣り，そのうち2 例 $(25 \%)$ は遗残尿管にも腫崵が発生していた（表 5 ).

表 5 腎孟腫場の手術術式と術後膀腃腫瘍の発生

\begin{tabular}{|c|c|c|}
\hline 術 後 & 例数 & \begin{tabular}{|c} 
術後膀胱腫湯の発生 \\
例数 (\%) \\
\end{tabular} \\
\hline $\begin{array}{l}\text { 腎尿管摘除術兼 } \\
\text { 膀胱壁切除術 }\end{array}$ & 24 & $2(8.3)$ \\
\hline 腎尿管摘除術 & 3 & $1(33)$ \\
\hline 腎摘除術 & 8 & $4(50)$ \\
\hline 計 & 35 & $7(20)$ \\
\hline
\end{tabular}

腎孟尿管に同時に腫瘍が発生していた10例では，腎尿 管摘除術兼膀胱壁切除術を 9 例に施行したにもかかわら ず 4 例 $(44 \%)$ に膀胱腫瘍が続発しており，腎孟のみに 腫緜のみられた 24 症例も加兄ると腎尿管摘除術兼膀胼壁 切除術施行例の続発性膀胖腫瘍の発生頻度は33例中 6 例 （18\%）に及んだ.

\section{6. 膀胱腫瘍の発生時期}

膀胱腫湟を併発した22例についてその発生時期をみる と腎孟腫瘍診断と同時に認められたものは20例中 7 例で あつた。術後発生したものは13例で，その期間は 3 力月 及至 26 月, 平均 9.8 力月ですべて 3 年以内に発生して いた。な抹13例中 2 例は膀胱腫瘍が同時発生もしていた もので，これらに対して腎尿管全摘除術及び膀脱部分切 除術を施行後に再び膀胼腫瘍が発生したものである.

また 2 例は膀脂腫瘍の治療後に腎盂腫瘍が発現したも ので，その期間は 3 年执よび 5 年 2 カ月であつた（表 $6)$.

\section{7. 膀胱腫瘍の発生部位}

膀胱腫瘍の発生部位をみると, 腎孟腫瘍と同時に発生 した 7 例中 5 例は腎孟と同側であり， 2 例は膀胀内に多 発していた. 一方, 腎盂腫瘍の術後に発生した膀胖腫瘍 13例では腎盂と同側に発生したのは 6 例であり，患側尿 管周囲と無関係な位置に発生したのは 7 例であつた。

8. 病理学的所見

腎孟腫瘍の grade 及び stage と尿管・膀胱腫瘍 の併 発についてみると, grade I では11例中のうち 3 例 (27 
表 6 膀胱腫瘍20例の発生時期

\begin{tabular}{c|c}
\hline 時 $\quad$ 期 & 例 数 \\
\hline 同 時 & 7 \\
\hline 術 後 & 2 \\
\hline 術 後 & 13 \\
\hline $0 \sim 3$ 月 & 4 \\
\hline $4 \sim 6$ & 3 \\
\hline $7 \sim 9$ & 2 \\
\hline $10 \sim 12$ & 1 \\
\hline $13 \sim 14$ & 2 \\
\hline $25 \sim 36$ & 1 \\
\hline
\end{tabular}

術後発生13例の中に同時発生例2症例を含め ている.

(慈大, 泌, 1980)

\%) に尿管, 膀脱に腫瘍が併発し， grade II では30例中 12例 (40\%) であつた。 また grade IIIの3例, 未分化癌 の 2 例括よび Non papillary (carcinoma in situ) の 2 例 では併発例は認められなかつた。

一方, stage I では21例のらち6例 $(28.5 \%)$, stage II では12例中 5 例 $(41 \%)$, stage III では13例中 4 例（31 \%)，stage IVでは 2 例中 1 例（50\%）に尿管・膀朕腫瘍 の併発が認められた（表 7 ）.

また腎盂腫場と併発した膀胱腫瘍の grade を比較して みると，腎孟腫瘍の grade よりも膀脱腫瘍の grade が 高かつたものは10例中 1 例の及で，この例は術後 3 カ月 目に続発したものであつた。他の 9 例では膀脱腫瘍の grade は腎盂腫場のそれと同等ないしは低かつた（表 8 ). また続発性膀胱腫瘍 8 例のらち 7 例は表在性であ り，浸潤性のものは 1 例のみであつた.

\section{考察}

腎孟腫瘍は腎実質腫瘍に比較し少なくわれわれの 教室の統計では全腎腫瘍の19\%を占めるにすぎない"1). Latham ${ }^{27}$ も諸家の報告をまとめ, 8 14\%，約 $12 \%$ 前後 と報告し，また同じ尿路腫瘍であつても膀胱腫瘍と比較 すると本症はさらに低く，Williams ${ }^{3}$ は，膀胱腫瘍 2,770 例に対し腎孟腫瘍は43例，64：1 であつたと報告してお り，尿路腫瘍の中で比較的稀な疾患である.

腎克腫瘍は尿管腫瘍とともに上部尿路上皮腫瘍として 報告されていることが多いが4)，われわれは先に腎㙉腫 瘍 ${ }^{1)}$ および尿管腫瘍5) についてそれぞれの臨床成績を報 告したので，今回腎孟腫瘍を中心として多中心性に発生
表 7 腎昷腫瘍の Grade と尿管および膀胱腫瘍の 併発

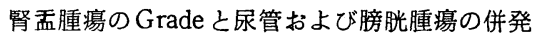

\begin{tabular}{l|c|c|c|c}
\hline & 腎孟腫瘍 & 膀腅腫瘍 & 尿管腫瘍 & $\begin{array}{c}\text { 膀 } \\
\text { 脉管腫瘍 }\end{array}$ \\
\hline Grade I & 11 & 1 & 1 & $\cdot 1$ \\
\hline Grade II & 30 & 7 & 4 & 1 \\
\hline Grade III & 3 & 0 & 0 & 0 \\
\hline Undifferentiated & 2 & 0 & 0 & 0 \\
\hline \multicolumn{1}{c|}{ Non- papillary } & 2 & 0 & 0 & 0 \\
\hline
\end{tabular}

(慈大, 泌, 1980)

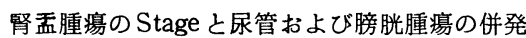

\begin{tabular}{c|c|c|c|c}
\hline & 腎孟腫痬 & 膀胱腫瘍 & 尿管腫瘍 & $\begin{array}{c}\text { 膀 胱・ } \\
\text { 水管腫瘍 }\end{array}$ \\
\hline Stage I & 21 & 1 & 3 & 2 \\
\hline Stage II & 12 & 4 & 1 & 0 \\
\hline Stage III & 13 & 3 & 1 & 0 \\
\hline Stage IV & 2 & 0 & 1 & 0 \\
\hline 計 & 48 & 8 & 6 & 2 \\
\hline
\end{tabular}

（慈大, 泌, 1980)

表 8 腎孟腫瘍と膀胱腫瘍の Grade

\begin{tabular}{l|c|c|c|c}
\hline \multirow{2}{*}{$\begin{array}{l}\text { Grade of } \\
\text { Pelvic lesion }\end{array}$} & \multicolumn{4}{|c}{ Grade of bladder lesion } \\
\cline { 2 - 5 } & Grade I & Grade II & Grade III & $\begin{array}{c}\text { Undiffe- } \\
\text { rentiated }\end{array}$ \\
\hline Grade I & 1 & 1 & 0 & 0 \\
\hline Grade II & 2 & 6 & 0 & 0 \\
\hline Grade III & 0 & 0 & 0 & 0 \\
\hline Undifferentiated & 0 & 0 & 0 & 0 \\
\hline
\end{tabular}

(慈大, 泌, 1980)

する尿路上皮腫瘍の検討を行つた。

腎盂腫瘍飞併発する尿管・膀朕腫瘍は Kimball ${ }^{6)}$ （1934）が始めて注目し，約68\%に及ぶことを指摘して 注目されるようになつたが，その後 Kaplan ${ }^{7)}$ は133例中 45例 $(35 \%)$, Johansson ${ }^{8)}$ は 94例中 36 例 $(38 \%)$ 飞併発 したと報告し，他の部位の尿路にも同じ移行上皮性の腫 瘍の発生することは，腎孟移行上皮癌の 1 つの特徵とさ れている.教室例では54例中26例 $(48 \%)$ と高率に出現 していた.

腎盂腫瘍の性別による発生頻度は腎細胞癌と同様に男 
子に多くみられ，その男女比は1.8:1 4.4: $1^{8) 9110}$ といわれて拈り, 自験群でも $3: 1$ であるが, 男子が女 子に比べて尿路の他の部位にも発生しやすい傾向がみら れた。

$\mathrm{Kaplan}^{7)}$ も腎㙉のみの腫瘍の場合は男子75\%，女子 25 \%に対し，他の尿路にも腫瘍が併発した例では男子 82.2 \%，女子 $17.8 \%$ と男子により多いと同様の報告をしてい る。

一方, 腎盘腫瘍の発生年齢に関しては, 教室例では腫 瘍が尿管や膀胱に同時発生した症例では, 平均65歳とよ り高龄であつた。しかし Kaplan")らの腎盂のみの腫瘍 では57.8歳, 他の尿路にも併発した症例では 56.8 歳と差 はなかつたといら意見もある。

手術時の腫瘍の範囲と, 乞の後, 続発した尿路上皮腫 瘍の関係をみると, 手術時上部尿路の広範囲に腫瘍が発 生している場合に，膀脱腫瘍の発生頻度は高い傾向が認 められている。.Kakizoe ${ }^{11}$ は腎孟のみの腫瘍18例では同 時あるいは異時性に膀胱腫瘍が発生したのは 5 例，18 \%であるのに対し，腎孟腫瘍に尿管腫瘍が併発した12例 では，9例， $75 \%$ であつたと報告している.

腎盂腫瘍，特に移行上皮癌の手術術式としては，尿管 口周辺の膀胱壁を含めた腎尿管全摘除術が一般に必要と されている．これは腎孟移行上皮癌には尿管腫瘍の併発 が高頻度にみられること，拈よび遺残尿管に腫瘍が発生 する potency があるからであり, 単腎や腎機能あるい は全身状態のきわめて悪い症例をのぞいて ${ }^{10)}$, 当教室で は腎扣よび全尿管を膀胱壁を含めて摘除することを原則 としている。

尿管断端の腫瘍の発生率は, Strong ${ }^{10)}$ は諸家の報告を まとめ187例の成績では84例（45\%）であつたとのべて いる. 当教室でも 2 例の遺残尿管腫瘍を確認し二次的に 摘除術を施行しているので, 腎盂腫瘍の発生年齢が高年 㱓であり，手術の侵襲がますことを考慮しても，尿管口 周辺の膀脱壁を含めた腎尿管全摘除術がすぐれていると 思われる。

また Taylor ${ }^{13}$ は腎尿管全摘除術を行なつた13例中再 発例は膀胼腫湟の 2 例 (15.4\%) で，単に腎摘除術を施 行した場合の尿管括よび膀胱腫瘍の再発率 $33 \%$ 上り再発 率が低いとのべ, Williams ${ }^{3}$ も膀胱壁まで切除した17例 では 5 例に，切除しなかつた20例では12例に膀脱腫瘍が 発生して括り,さらにこれらの膀胱腫瘍17例中12例は尿 管口附近にみられることから，尿管摘出時に膀脱壁を含 めて摘除することが大切であるとのべている。しかし高
井 ${ }^{14)}$ は腎孟腫瘍 17 例について，腎尿管摘除例 5 例では続 発した膀胱腫瘍は 1 例 $(20 \%)$ であり，膀胼壁切除まで 行なつた12例では 3 例（25\%）で両者に差がなかつたと 報告しまた Strong ${ }^{15)}$ 子腎尿管全摘除術を施行した22例 中 7 例 $(31.8 \%)$ に膀胼腫瘍は続発しているのに対し, 膀胱壁切除術を施行しなかつた46例では10例（22\%）で あり，術式と続発する膀胖腫瘍とは無関係であるという 成績を示している。

われわれの症例で尿管腫瘍を併発した腎盂腫瘍も含め ると腎尿管全摘除術を施行した33例中 6 例（18\%）は膀 胱腫瘍を続発している。また術後に発生した膀脱腫瘍 13 例のうち 7 例は患側尿管口と無関係な位置にあったこと を考学ると，腎尿管摘除術を施行する第 1 の目的は遺残 尿管腫瘍の予防にあると考支ている。

術後, 膀脱腫瘍の発生した13例の，その期間は 3 力月 乃至26力月，平均9.8力月であつた。 William ${ }^{3)}$ も術後, 膀胱腫瘍発生までの平均期間は15力月で, 1 例のみが 3 年以上たつていたと報告し，Johnson ${ }^{16)}$ も同様飞 続発し た膀胼腫瘍 13 例中 10 例は 3 年以内に生じその平均期間は 2 年であつたとのべている。こうした事実にもとづき教 室では腎孟腫場の手術後，定期的な膀胱鏡検查を最初の 3 年間は 3 力月毎に行い, 次の 2 年間は 6 力月毎に, そ の後は 1 年毎に行らようにしている.

また膀胱腫瘍の治療後， 3 年および 5 年 2 カ月目にそ れぞれ腎孟腫瘍が 発現した例があり，Johnson ${ }^{16)}$ も腎盂 腫瘍 49 例中 5 例は， $4 \sim 21$ 年前に膀脂腫瘍の治療をうけ ていたとのべて扣り, 膀胖腫瘍の患者にも術後長期間に 亘つて定期的な上部尿路の検査が必要であうう.

病理学的所見では表 1 のごとく, 腎盘腫瘍の grade が 高い例ほど腫瘍の浸潤傾向が強かつたが，Rubenstein ${ }^{10)}$ も腎盂腫瘍の grade と stage とを比較し同様の結果を示 している.また，Murphy ${ }^{9}$ は grade I の腎孟腫瘍の49例 では stage I が47例 $(98 \%$ ) で, stage II 及び IIIは各々 1 例のみ認められたと報告している。

教室例では腎盂腫瘍の grade I 及び II の症例 に 膀脱 腫瘍の併発が多い傾向がみられたが， Rubenstein ${ }^{10)}$ Lathum $^{2)}$ も同様の事実を指摘している．また腎盂腫瘍の stage と膀脂腫瘍の併発頻度には有意な美は認められな かつた。

併発膀胱腫瘍の grade は 10 例中 9 例が腎孟腫瘍の grade と同等ないしはそれより低かつた。この点に関し て Williams ${ }^{3}$ 子同様に, 続発性膀胱腫瘍13例のうち, 12 例が腎孟腫瘍と同等ないしは低かつたとのべている.し 
かし，腎孟腫痬と併発した膀胱腫湯とは特に一定した関 係は認められないといら報告 ${ }^{10)}$ あり，今後の長期の多 数症例による検討が必要だと思われる。

\section{結語}

（1）腎孟腫瘍54例中，尿管または膀胱腫瘍を併発（同 時および異時発生）したものは26例（48\%）であつた。 また上部尿路の広範囲に腫湯が発生している場合, 膀胱 腫瘍の併発頻度は特に高かつた。

(2) 対象54例の平均年齢は59歳であるが，层管や膀胱 に腫将が同時発生例11例では平均年齢65藏とより高齢で あつた。

(3) 男子は女子に比べて腎昷腫瘍が多いのみならず, 㽷路の他の部位にも多発しやすい傾向がみられた。

(4) 腎尿管摘除術兼膀胱壁切除術施行例の続癹性膀胱 腫瘍の発生頻度は33例中 6 例 $(18 \%)$ であつたが，手術 時腎孟のみに腫痬がみられた24例では2 例 $(8.3 \%)$ と 再発率は低かつた。

(5)腎孟腫煌の術後に膀胱腫晹の発生した13例の期間 は3 月乃至26力月, 平均9.8力月であつた.

(6) 膀胱腫瘍の発生部位は, 腎血腫瘍と同時に発生し た場合は患側に多くみられ，術後に発生した症例では患 側とは無関係であつた。

(7)膀胱腫陽の grade は腎孟腫焬の grade と類似し ている場合が多く，また多くは表在性腫瘍であつた。

（本論文の要旨は第23回腎臓学会総会で報告した。）

\section{文献}

1）菱沼秀雄, 增田富士男, 佐々木忠正 : 腎血腫湟 の臨床的研究. 日泌尿会誌, 68, 780-787, 1977.

2) Latham, H.S. and Kay, S.: Malignant tumors of the renal pelvis. Surg. Gynec. \& Obst., 138, $613-623,1974$.

3) Williams, C.B. and Mitchell, J.P.: Carcinoma of the real pelvis: A review of 43 cases. Brit. J. Urol., 45, 370-376, 1973.

4) 早川正道 : 上部尿路上皮性腫晹の臨床的ならび に細胞学的研究. 日泌尿会誌, 69, 1422-1431,
1978.

5) 荒井由和, 增田富士男, 菱沼秀雄 : 尿管腫湟の 臨床的研究. 日泌尿会誌, 69, 110-116,1978.

6) Kimball, F.N. and Ferris, H.W.: Papillomatous tumor of the renal pelvis associated with similar tumors of the ureter and bladder. J. Urol., 31, 257-304, 1934.

7) Kaplan, J.H., McDonald, J.R. and Thompson, G.J.: Multicentric origin of papillary tumors of the urinary tract. J. Urol., 66, 792-804, 1951.

8) Johansson, S., Angervall, L., Bengtsson, U. and Wahlqvist, L.: A clinicopathologic and prognostic study of epithelial tumors of the renal pelvis. Cancer, 37, 1376-1383, 1976.

9) Murphy, D.M., Zincke, H. and Furlow, W.L. : Primary grade 1 Transitional cell carcinoma of the renal pelvis and ureter. J. Urol., 123, $629-631,1980$.

10) Rubenstein, M.R., Walz, B.J. and Bucy, J.G.: Transitional cell carcinoma of the Kidney: 25-year experience. J. Urol., 119, 594-597, 1978.

11) Kakizoe, T., Fujita, J., Murase, T., Matsumoto, K. and Kishi, K.: Transitional cell carcinoma of the bladder in patients with renal pelvic and ureteral cancer. J. Urol., 124, 17-19, 1980.

12) Stong, D.W., Pearse, H.D., Tank, E.S. and Hodges, C.V.: The ureteral stump after nephroureterectomy. J. Urol., 115, 654655, 1976.

13) Taylor, W.N.: Tumors of the kidney pelvis. J. Urol., 82, 452-458, 1959.

14) 高井修道: 泌尿器科手術の遠隔予後. 日泌尿会 誌, 64, 685-694, 1973.

15) Strong, D.W. and Pearse, H.D.: Recurrent urothelilial tumors following surgery for transitional cell carcinoma of the upper urinary tract. Cancer, 38, 2178-2183, 1976.

16) Johnson, D.E., de Berardinis, M. and Ayala, A.G.: Transitional cell carcinoma of the renal pelvis. South. Med. J., 67, 1183-1186, 1974. （1981年 4 月 23 日受付） 